\title{
Ground- and Surface-Water Interactions of a Pumice Aquifer in a Headwaters Watershed: Round Meadow, Fremont-Winema National Forest, Oregon, USA
}

\author{
Jonathan M. Weatherford, Michael L. Cummings \\ Department of Geology, Portland State University, Portland, OR, USA \\ Email: cumminm@pdx.edu
}

How to cite this paper: Weatherford, J.M. and Cummings, M.L. (2016) Ground- and Surface-Water Interactions of a Pumice Aquifer in a Headwaters Watershed: Round Meadow, Fremont-Winema National Forest, Oregon, USA. Journal of Water Resource and Protection, 8, 1010-1034.

http://dx.doi.org/10.4236/jwarp.2016.811081

Received: February 22, 2016

Accepted: October 23, 2016

Published: October 26, 2016

Copyright $\odot 2016$ by authors and Scientific Research Publishing Inc. This work is licensed under the Creative Commons Attribution International License (CC BY 4.0).

http://creativecommons.org/licenses/by/4.0/ (c) (i) Open Access

\begin{abstract}
Plinian pumice fall from the Holocene eruption of Mount Mazama in the Cascade volcanic arc is an unconfined, perched aquifer in south-central Oregon. The pumice aquifer provides near-surface groundwater storage that maintains biologically diverse wetland environments. Wetland environments reflect post-eruption disruption of the once uniform pumice blanket by fluvial and lacustrine processes operating within the template of the pre-eruption landscape. In the $8.6 \mathrm{~km}^{2}$ Round Meadow watershed the pumice aquifer interacts with a seasonally flooded meadow, fen, springs, and perennial stream. The laterally uniform, isotropic pumice aquifer is disrupted by flat-bottomed ephemeral stream valleys that drain to the seasonally flooded meadow. Surface water levels in the seasonally flooded meadow are controlled by a knickpoint developed on bedrock. The underlying aquifer is confined by a layer of glass-rich diatomaceous silt grading upward to organic-rich silt. Here, the aquifer is comprised of remnants of the pumice deposit, lag sand, and reworked pumice. The water level in the confined aquifer is maintained by recharge from the unconfined pumice aquifer following flow pathways beneath ephemeral stream valleys. The fen is developed on a down-thrown block of welded tuff and pre-eruption diatomaceous silt. Water levels in the fen are sensitive to inter-annual variations in precipitation. Low discharge, low temperature $\left(5.0^{\circ} \mathrm{C}\right.$ to $6.5^{\circ} \mathrm{C}$ ), and low conductivity (30 to 50 $\mu \mathrm{S} / \mathrm{cm}$ ) springs appear to be fracture controlled and rising through welded tuff. Spring discharge and seepage through pumice from the welded tuff support perennial flow in the creek that also carries discharge from the seasonally flooded meadow when water levels are high enough to cross the knickpoint.
\end{abstract}

\section{Keywords}

Pumice Aquifer, Perched Aquifer, Oregon, Mount Mazama 


\section{Introduction}

The Round Meadow watershed (Figure 1) has flow paths and interactions between the ground- and surface-water systems that are similar to those observed elsewhere in the pumice-blanketed landscapes of south central Oregon [1]-[3]. The perched pumice aquifer provides near-surface groundwater storage that maintains biologically diverse wetland environments in the rain shadow of the Cascade Range. The Round Meadow watershed was selected for particular study because it has four characteristics that allowed a better constrained analysis. 1) The pumice blanket from the Plinian eruption of Mount Mazama is effectively isotropic and laterally homogenous; 2) The pumice aquifer is perched above low permeability bedrock and regolith; 3) Round Meadow is the highest elevation wet meadow in the Walker Rim fault block and precipitation falling within the watershed is the predominant water input to the pumice aquifer; 4) There is a single outlet channel, Sellers Creek, and all streamflow that leaves the meadow runs

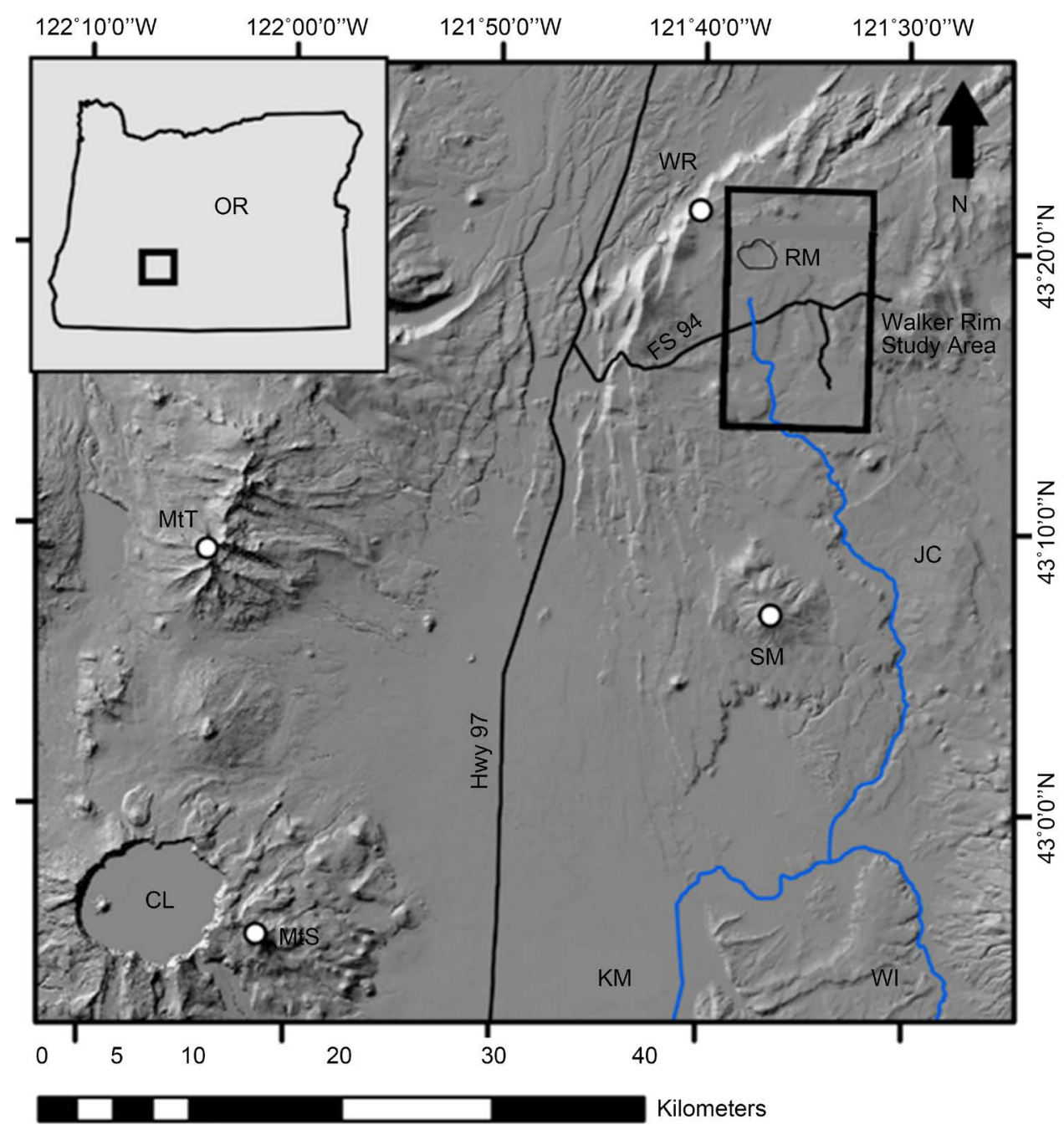

Figure 1. Location map of the Walker Rim study area and the Round Meadow watershed (RM). CL: Crater Lake, MtS: Mt Scott, MtT: Mt Thielsen, KM: Klamath Marsh, WI: Williamson River, SM: Sugarpine Mountain, JC: Jack Creek, WR: Walker Rim. 
through this channel (Figure 2). During drought conditions, these characteristics allowed delineation of hydrologic systems that while they were united by proximity, functioned independently.

At the start of this study the hydrogeologic system at Round Meadow within the Round Meadow watershed was known to include a seasonally flooded meadow, a fen [2], springs, and a short reach of perennially flowing stream, but interactions between surface- and ground-water were otherwise unknown. For the current study, data were

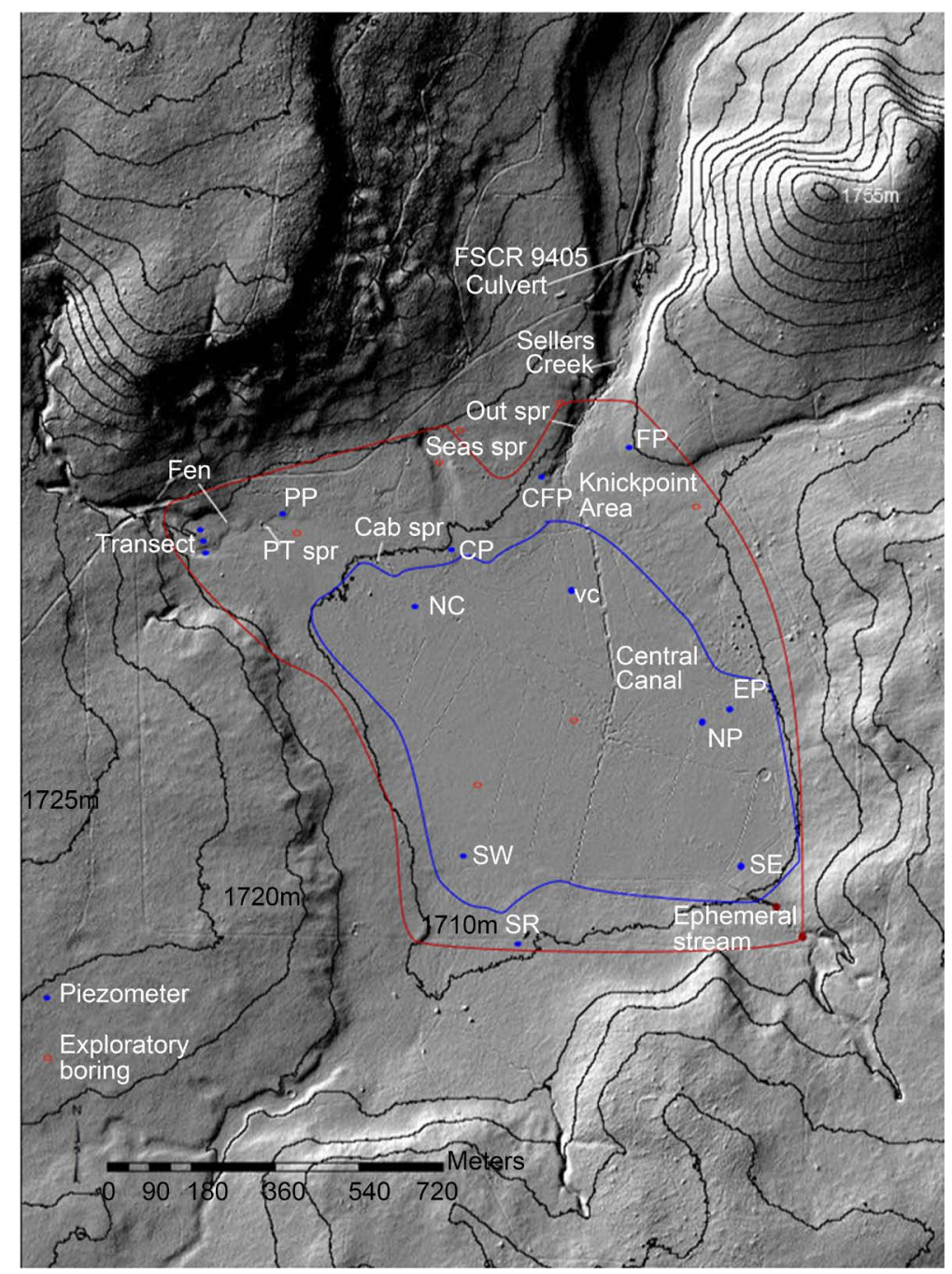

Figure 2. The seasonally flooded meadow of the Round Meadow watershed lies within the blue line. Between the blue line and the red line is the meadow fringe where the lodgepole pine forest has been thinned. Beyond the red line the watershed is forested. Locations of auger and vibracore holes where piezometers were installed are indicated as blue dots. Exploratory borings used to determine stratigraphic relations are indicated by red dots. Pine tree (PT spr), cabin (Cab spr), and outlet (Out spr) springs are indicated as is a seasonal spring (Seas spr) at the head of valley in the northern meadow fringe. Two red dots at the SE corner mark the locations where an ephemeral stream was gaged on 7-March-2015 and 13-May-2016 and where it soaked into the pumice. FSCR 9405 culvert marks the point on Sellers Creek taken as the outlet for the Round Meadow watershed. 
gathered on stratigraphic relations, spring and stream discharge, depth to water table, water temperature and electrical conductivity, hydrogeochemistry, and aquifer properties starting July-2010 and continuing through water year 2015 (WY2015). The extended period of observation provided context for data gathered during the WY2014 drought when distinctions and interactions among spatially related components of the hydrogeologic system became apparent.

The hydrogeologic system at Round Meadow is comprised of five components 1) the perched pumice aquifer, 2) the seasonally flooded meadow, 3) the northwest wetland and fen, 4) springs, and 5) perennial stream. The first three components evolved in response to widespread disturbance produced by the eruption of Mount Mazama (a.k.a. Crater Lake, Figure 1) at 7600 yr. B.P. [4]. The remaining two were inherited from the pre-eruption landscape.

\section{Location of the Round Meadow Watershed}

The Round Meadow watershed and Walker Rim are in the rain shadow of the Cascade Range, about $70 \mathrm{~km}$ northeast of ancestral Mount Mazama (modern Crater Lake) (Figure 1). The Round Meadow watershed is herein defined as the area drained by Sellers Creek upstream from the point the creek passes under US Forest Service connector road 9405 (FSCR 9405) at UTM Zone 10, 612005 E, 4799547 N (Figure 2). The area of the watershed was determined using Esri's ArcGIS Hydro tool and a Digital Elevation Model (DEM) created from LiDAR downloaded from the US Geological Survey (http://earthexplorer.usgs.gov/, accessed April 2015) and originally collected by Watershed Sciences Inc. with an average pulse spacing of $0.35 \mathrm{~m}$. The watershed is slightly greater than $8.57 \mathrm{~km}^{2}$. Elevation ranges from $1703 \mathrm{~m}$ to $1792 \mathrm{~m}$. Lodgepole pine forest with sparse stands of ponderosa pine and understory dominated by bitterbrush are predominant. Round Meadow, the seasonally flooded meadow, for the purposes of this study is circumscribed by the $1710 \mathrm{~m}$ contour (Figure 2). Within the $1710 \mathrm{~m}$ contour the seasonally flooded meadow is approximately $0.42 \mathrm{~km}^{2}$. Between the seasonally flooded meadow and the lodgepole pine forest, trees were removed as part of the management of the meadow system. This area, the meadow fringe, is approximately 0.81 $\mathrm{km}^{2}$.

\section{Perched Pumice Aquifer}

The Plinian pumice fall from the cataclysmic eruption of Mount Mazama (now Crater Lake) at about 7600 yr B.P. blanketed the Round Meadow watershed with approximately $2.8 \mathrm{~m}$ of pumice. The contact and stratigraphic relations of the Plinian pumice fall were determined from hand-drilled auger holes and confirmed in the seasonally flooded meadow by three continuous cores (end of hole ranged from 2.7 to $3.5 \mathrm{~m}$ below ground surface) that recovered material from the surface to nearly $60 \mathrm{~cm}$ into pre-eruption deposits. The Plinian pumice fall is divided into upper ( 1.2 m thick) and lower ( $\sim 1.6 \mathrm{~m}$ thick) units based on composition, grain size, and sorting. These lower and upper pumice units are sub-divisions of the upper pumice described by Young [5]. The pumice-hosted 
aquifer is perched over relatively low permeability bedrock and pre-eruption regolith and is unconfined except in the seasonally flooded meadow where the upper confining layer is diatomaceous silt.

The physical properties of pumice from the Plinian pumice fall of Mount Mazama were investigated by Klug et al. [6] for sites near the source volcano. The bulk vesicularity of pumice clasts was between 75 and 88 percent and clasts had high pore interconnectivity ( $>90$ vol. \%). From these data, saturated pumice clasts are predominantly water and the pores hosting water are interconnected. However, movement of water among pores within pumice clasts is not well understood [7] [8].

The Plinian pumice fall has laterally persistent physical properties at the scale of the Round Meadow watershed. Isotropy of the pumice aquifer was demonstrated by records from pressure transducers installed in two piezometers completed in the pumice aquifer in the seasonally flooded meadow. The piezometers were approximately $400 \mathrm{~m}$ apart and pressure and temperature were recorded every 30 minutes (Figure 3 ). Although the piezometers are emplaced at different depths, resulting in different absolute pressure readings, the pattern of the two tracks vary closely. The greatest percent difference in change at each transducer for every 30 minute interval from 12-July-2014 to 26 -October-2014 was $0.057 \%$, indicating a high degree of similarity in fluctuations of the water table at the 2 piezometers.

The hydraulic conductivity, $K$, of the lower pumice unit beneath the seasonally flooded meadow was determined from two slug tests [9]. Two piezometers located $10 \mathrm{~m}$ apart and screened with hand-sawn slits near the base and open at the bottom were filled and then water levels were measured every 2 minutes until $90 \%$ of the added water had drawn down according to the Hvorslev method [10]. The hydraulic conductivity

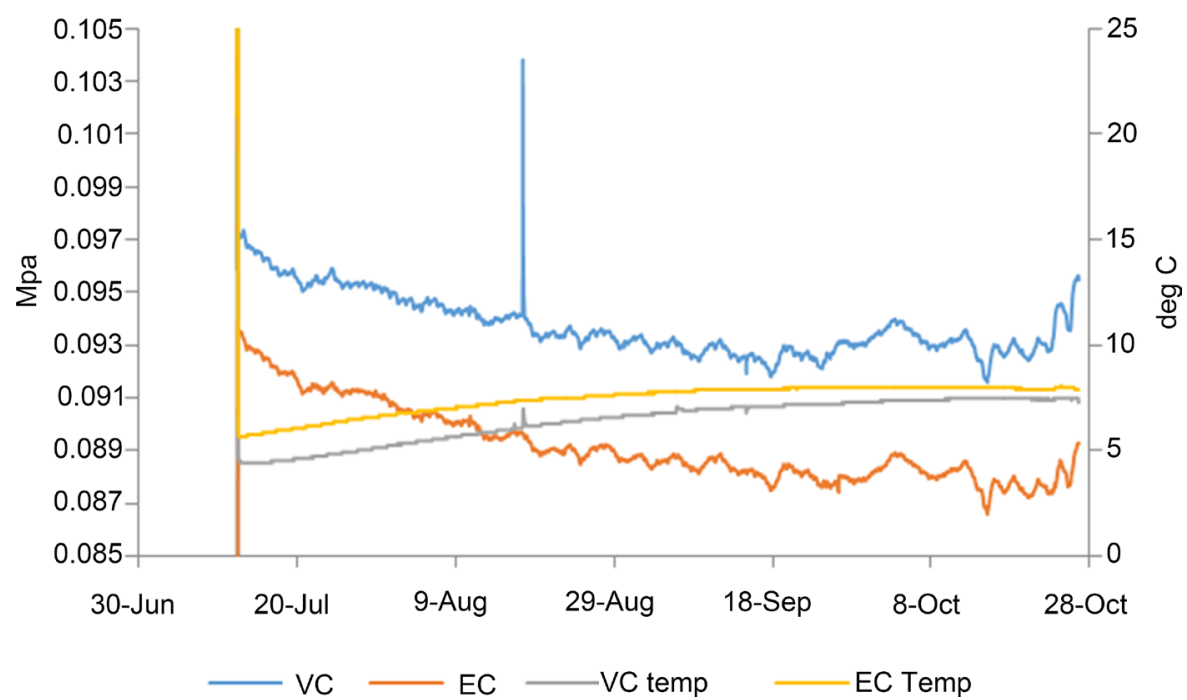

Figure 3. Water pressure in $\mathrm{Mpa}$ and temperature in degrees $\mathrm{C}$ for two piezometers screened in the pumice aquifer approximately $400 \mathrm{~m}$ apart in the seasonally flooded meadow. The spike in the graph of the vibracore curve (VC) in August was when it was filled to monitor drawdown for slug tests and the small drop in September was due to purging during the collection of a sample for isotope analysis. These data were collected between 12-July and 26-October-2014. 
for the lower pumice unit in two separate tests was $6.3 \times 10^{-4}$ and $1.9 \times 10^{-4} \mathrm{~cm} / \mathrm{s}$. At the Johnson Meadow fen, $8.5 \mathrm{~km}$ south of Round Meadow, hydraulic conductivity of the pumice aquifer was measured by stimulating the aquifer by constant pumping and observing the response. From this aquifer test, Aldous et al. [2] reported an average value for hydraulic conductivity of $1.4 \times 10^{-2} \mathrm{~cm} / \mathrm{s}$.

Storage in the pumice aquifer follows annual precipitation patterns. Recharge of the pumice aquifer occurs during spring snowmelt when water is released from snowpack. Highest groundwater levels are observed during and shortly after the freshet as infiltrated snowmelt migrates along flow paths in the aquifer. These flow paths follow pre-eruption topography and converge on the seasonally flooded meadow. During the relatively dry summer months storage in the pumice aquifer steadily declines as water moves along flow paths and evapotranspiration takes its toll. Weatherford [11] estimated losses to evapotranspiration over the watershed were $917 \mathrm{~mm}$ during the growing season of WY2014 (April-October).

Although physical properties of the pumice aquifer are laterally consistent at the scale of the Round Meadow watershed and the aquifer is isotropic, post-depositional lacustrine and fluvial processes have disrupted the continuity of the aquifer on a template dictated by pre-eruption topography and slope. The highest rate of disruption occurred shortly after the eruption as the drainage network developed and a shallow lake formed where the seasonally flooded meadow is located. Although disruption continues in the modern landscape, it is at a lower rate.

\section{Disruption to the Pumice Aquifer by Stream Network}

The network of ephemeral stream valleys within the watershed evolved from the rill network that formed shortly after the eruption. A similar evolutionary pattern was documented by Collins and Dunne [12] and Major and Mark [13] after the eruption of Mount St. Helens. The depth of scour was through the thickness of the pumice deposit where slopes were steeper, but commonly only through the upper pumice where slopes were less steep. During this phase the local base level was a shallow lake that developed where the seasonally flooded meadow is located (see below). Small deltas formed where streams discharged into the shallow lake and alluvium-floored, flat-bottomed valleys developed where slopes were low. In these settings, alluvium, composed mostly of glassy silt and fine-grained pumice sand, was deposited over remnants of the lower pumice unit that remained after the scour-dominated phase of valley development.

Surface conveyance of water during the freshet follows the course of the flat-bottomed ephemeral stream network, but this is short lived at best and may not occur in all years. During the period of study, surface flow in the ephemeral drainage network was observed only during site visits on 7-March-2015 and 13-May-2016 in the bedrock-floored ephemeral stream valley that enters the seasonally flooded meadow from the southeast (Figure 2). However, within the meadow fringe the averaged discharge of $4.8 \times 10^{-3}$

$\mathrm{m}^{3} / \mathrm{s}$ sank into the stream bed within approximately $130 \mathrm{~m}$ of the discharge measuring site. Similar loss of flow relations were documented by Cummings [14] in the pumice 
blanketed landscape on the east flank of the Cascade Range.

\section{Seasonally Flooded Meadow}

Infiltration into the pumice routs snowmelt into flow paths within the perched aquifer rather than producing runoff that is carried as surface flow in the drainage network. Since these stream valleys were shaped by topography of the pre-eruption landscape, groundwater moving through the aquifer moves toward the seasonally flooded meadow. However, in the seasonally flooded meadow the pumice aquifer is confined beneath diatomaceous silt and is separated from surface water that seasonally accumulates in the meadow. In addition, the confined aquifer lies below the elevation of a bedrock knickpoint that is the spill point for the surface water in the seasonally flooded meadow and the head of Sellers Creek.

The bedrock knickpoint is probably the result of displacement across an east-northeast-striking normal fault (down to the south). Movement along this inferred fault occurred prior to the eruption since there is no fault scarp cutting the Plinian pumice fall on Lidar images. Likewise, fossil vegetation (Figure 4) at the contact between a palesol developed on pre-eruption diatomaceous silt (Pliocene?) and the Plinian pumice fall suggests a wetland existed upstream from the knickpoint. Burial of the landscape by the Plinian pumice fall produced a short-lived topographic barrier at the knickpoint that allowed a shallow lake to develop where the seasonally flooded meadow is now present.

The presence and extent of the post-eruption lake are indicated by stratigraphic relations under the seasonally flooded meadow and the meadow fringe. At elevations

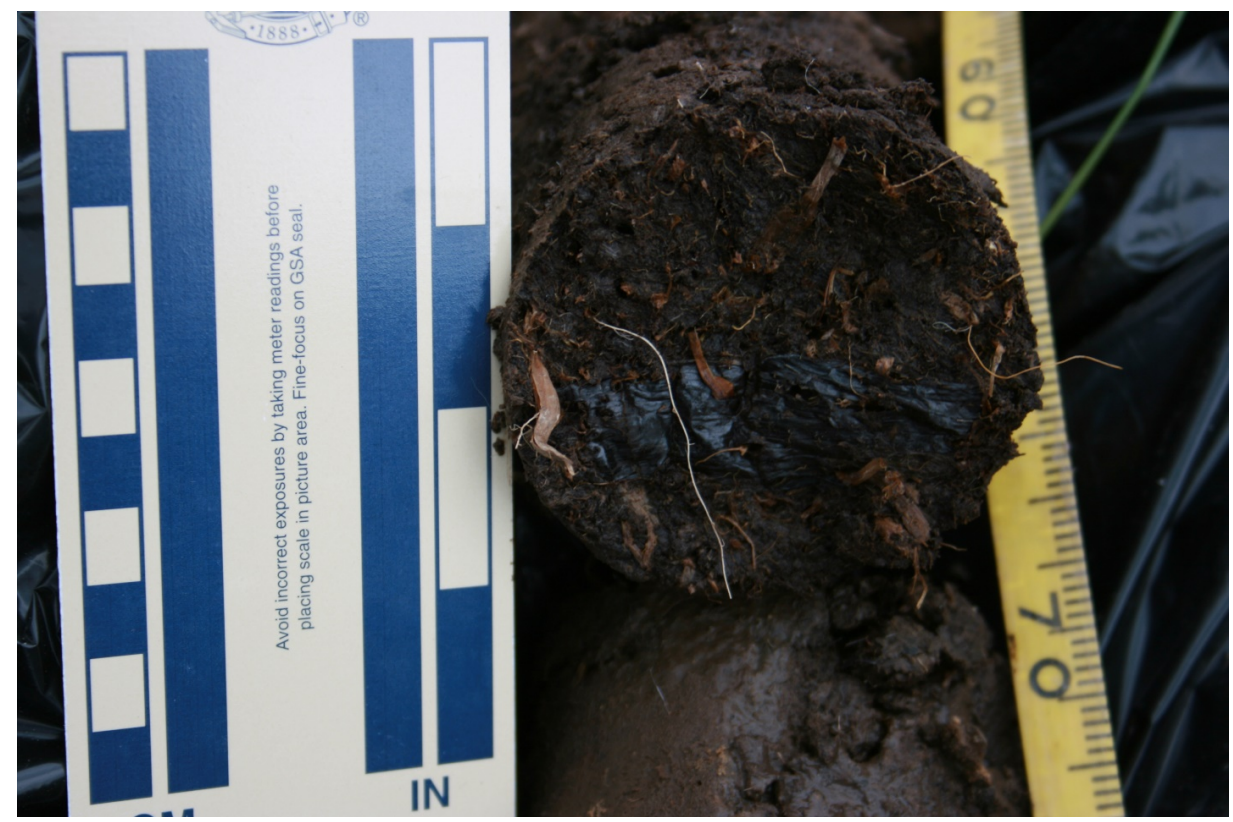

Figure 4. Fossil vegetation at the contact between the paleosol at the top of the diatomaceous silt (Pliocene?) and the bottom of the Plinian pumice fall. The contact with the paleosol was approximately $270 \mathrm{~cm}$ below ground surface. 
lower than $1710 \mathrm{~m}$, the upper pumice unit was absent and an erosion surface was cut into moderately well-sorted lapilli of the lower pumice unit (Figure 5(a) versus Figure 5(b) from meadow fringe). The basal contact of the lower pumice unit was sharp (Figure 6) against a paleosol developed from diatomaceous silt (Pliocene?). The erosion surface was directly overlain by $10-15 \mathrm{~cm}$ of medium-grained sand comprised of angular crystals, sub-rounded lithics, and pumice sand to granules. This layer is interpreted to be a lag deposit produced during erosion of the upper pumice unit. The lag sand graded upward into sub-rounded to sub-angular pumice granules to pebbles. Crystals and lithics were not present in this reworked pumice deposit. The reworked pumice layer graded upward into crudely bedded, glass-rich diatomaceous silt (Figure $5(\mathrm{a}))$.

The relatively low hydraulic conductivity of the post-eruption diatomaceous silt, $1.1 \times$

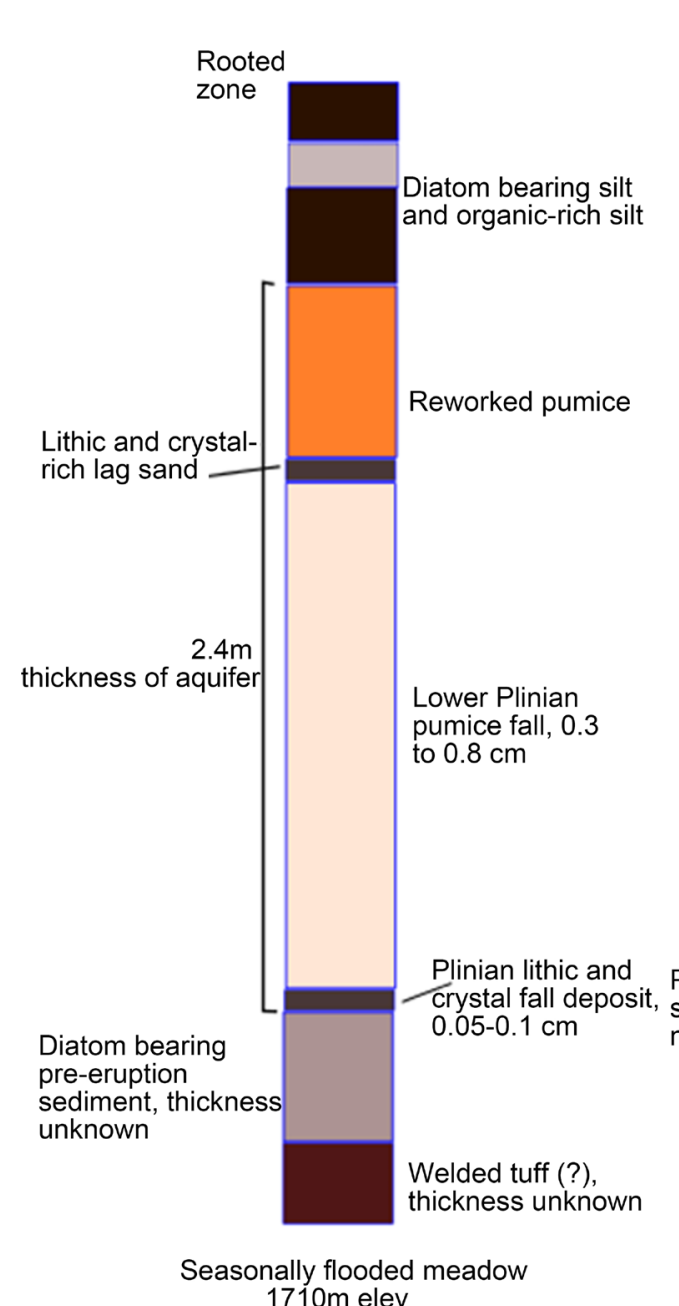

(a)

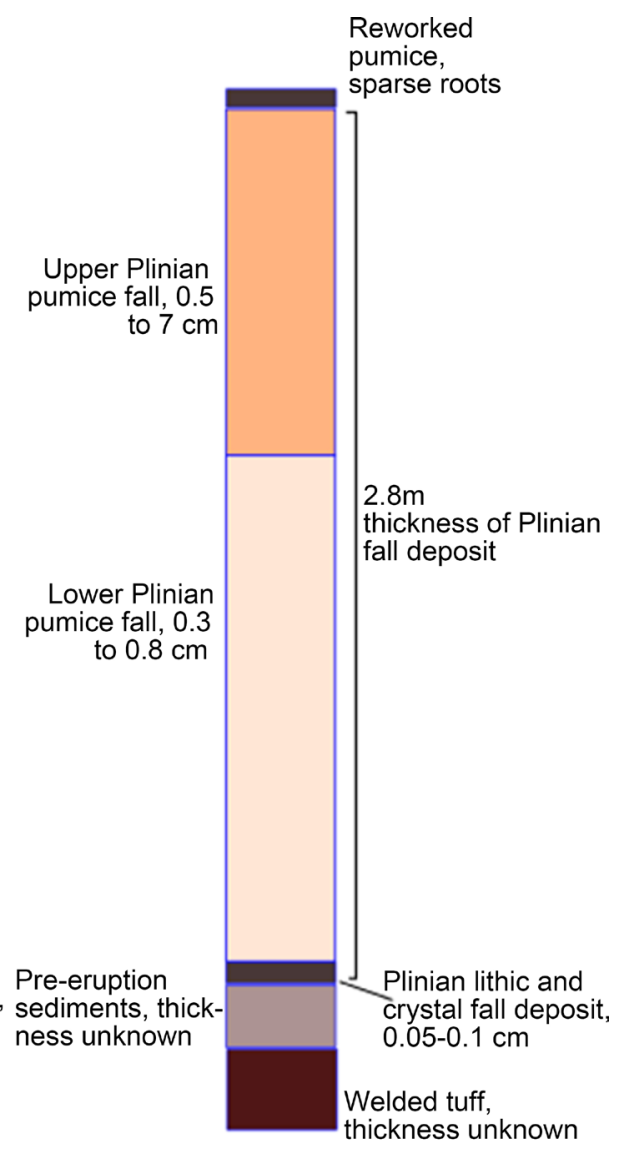

North ,eadow fringe $1715 \mathrm{~m}$

(b)

Figure 5. General stratigraphy of the seasonally flooded meadow at $1710 \mathrm{~m}$ (a) and the meadow fringe at about $1715 \mathrm{~m}$ (b). Thickness of the pre-eruption diatomaceous silt and the unwelded and welded zones of the welded tuff are unknown. The contact between the Plinian pumice fall and the paleosol developed from diatomaceous silt is shown in Figure 6. 


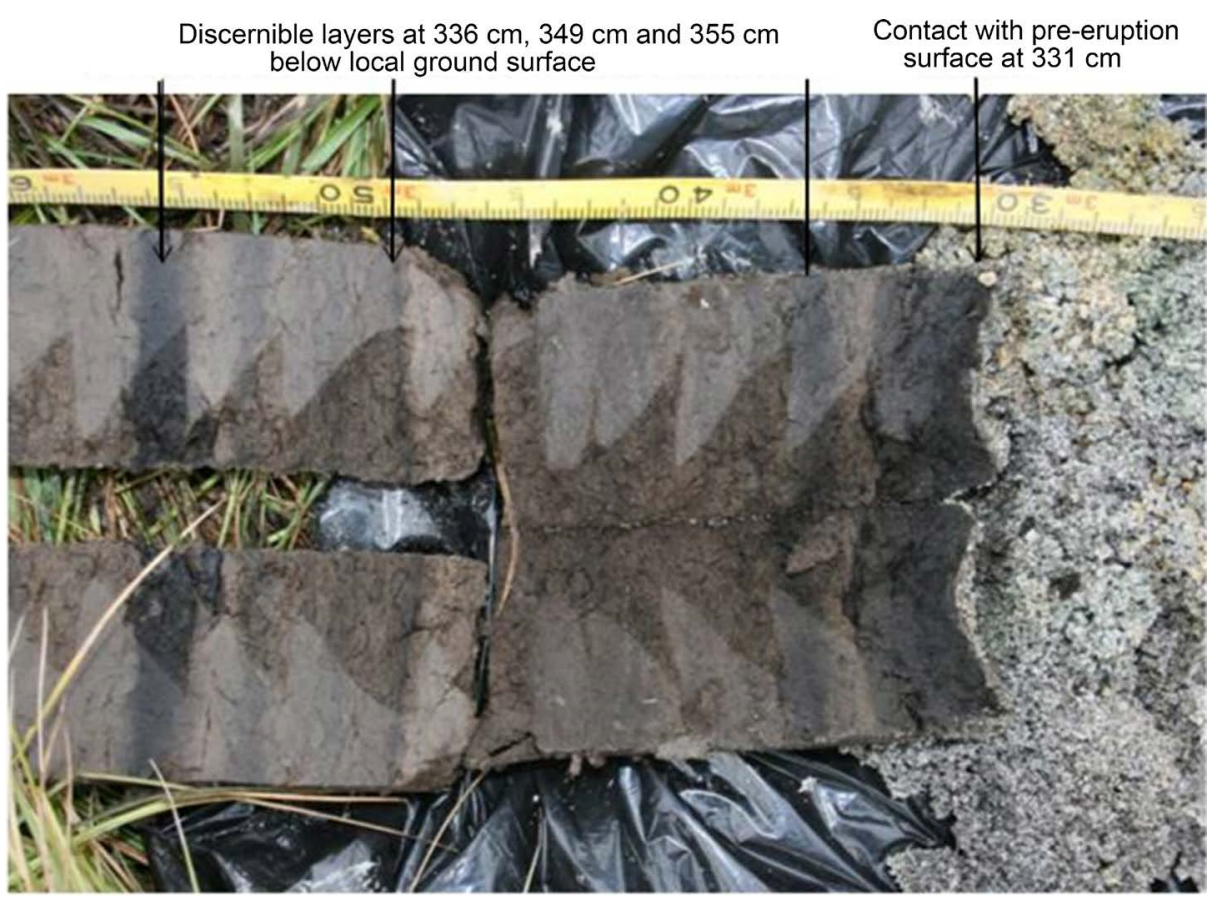

Figure 6. Photograph of core recovered from the seasonally flooded meadow. The contact between the Plinian pumice fall and paleosol developed from diatomaceous silt is sharp and $331 \mathrm{~cm}$ below local ground surface. The crystal-and lithic-rich base of the Plinian pumice fall is shown in this picture.

$10^{-5} \mathrm{~cm} / \mathrm{s}$, suggests the silt was a confining layer that separated groundwater in the hybrid (primary and reworked deposits) aquifer from surface water in the seasonally flooded meadow. The "pumice" aquifer in this area was comprised of the lower Plinian pumice fall unit, the lag sand, and the reworked pumice layer. The total thickness of the hybrid aquifer was 2.2 to $2.4 \mathrm{~m}$.

\section{Northwest Wetland and Fen}

The most ambiguous hydrogeologic setting in the Round Meadow watershed was a wetland located on the downthrown side of an east-northeast-striking normal fault cutting welded tuff in the northwest part of the meadow fringe (Figure 2 and Figure 7). During drought conditions of WY2014 it became apparent that surface-and ground-water interactions were complex. The wetland included a fen and was separated on the south from an ephemeral stream valley by a natural berm. Adding to the complications was a spring, pine tree spring, that discharged within an excavated depression and to the seasonally flooded meadow through a canal. The spring also lies where the natural berm was less prominent and the peat layer associated with the fen, although thinner, was exposed in the walls of the excavated depression. To investigate these relation, depths to water table in five piezometers in the wetland and one naturally occurring piping feature within the fen were measured periodically along with water temperature, electrical conductivity, oxidation-reduction potential, and $\mathrm{pH}$. Similar measurements were made at pine tree spring. In addition, hydrogen and oxygen isotopic ratios were determined 
for pine tree spring (Table 1) and multi-element chemical composition was determined for the piping feature.

A water sample collected from the pumice aquifer at the piping feature on 20-October-2012 when the water table was $8 \mathrm{~cm}$ below ground surface had oxidation-reduction potential measured at $76 \mathrm{mV}$. Iron and manganese concentrations were $1474 \mu \mathrm{g} / \mathrm{l}$ and $78 \mu \mathrm{g} / \mathrm{l}$, respectively. The sulfate concentration was $0.04 \mathrm{mg} / \mathrm{l}$. These concentrations, ORP value, and lack of discharge suggest the water in the aquifer was stagnant at the end of the growing season. Bicarbonate was $14.8 \mathrm{mg} / \mathrm{l}$, but charge balance errors were high suggesting problems with the field titration for bicarbonate. The $\mathrm{Na}^{+} / \mathrm{K}^{+}$ratio was 1.5 and $\mathrm{Ca}^{2+} / \mathrm{Mg}^{2+}$ ratio was 2.4.

The northern boundary of the wetland is a north-northeast-striking normal fault where welded tuff crops out in the footwall (A in Figure 7) and, farther west, in the bed of the ephemeral stream where it crosses the footwall near FSCR 9405. The southern boundary is an asymmetric berm that separates the higher elevation wetland on the north from the ephemeral stream valley on the south. The boundaries to the east and

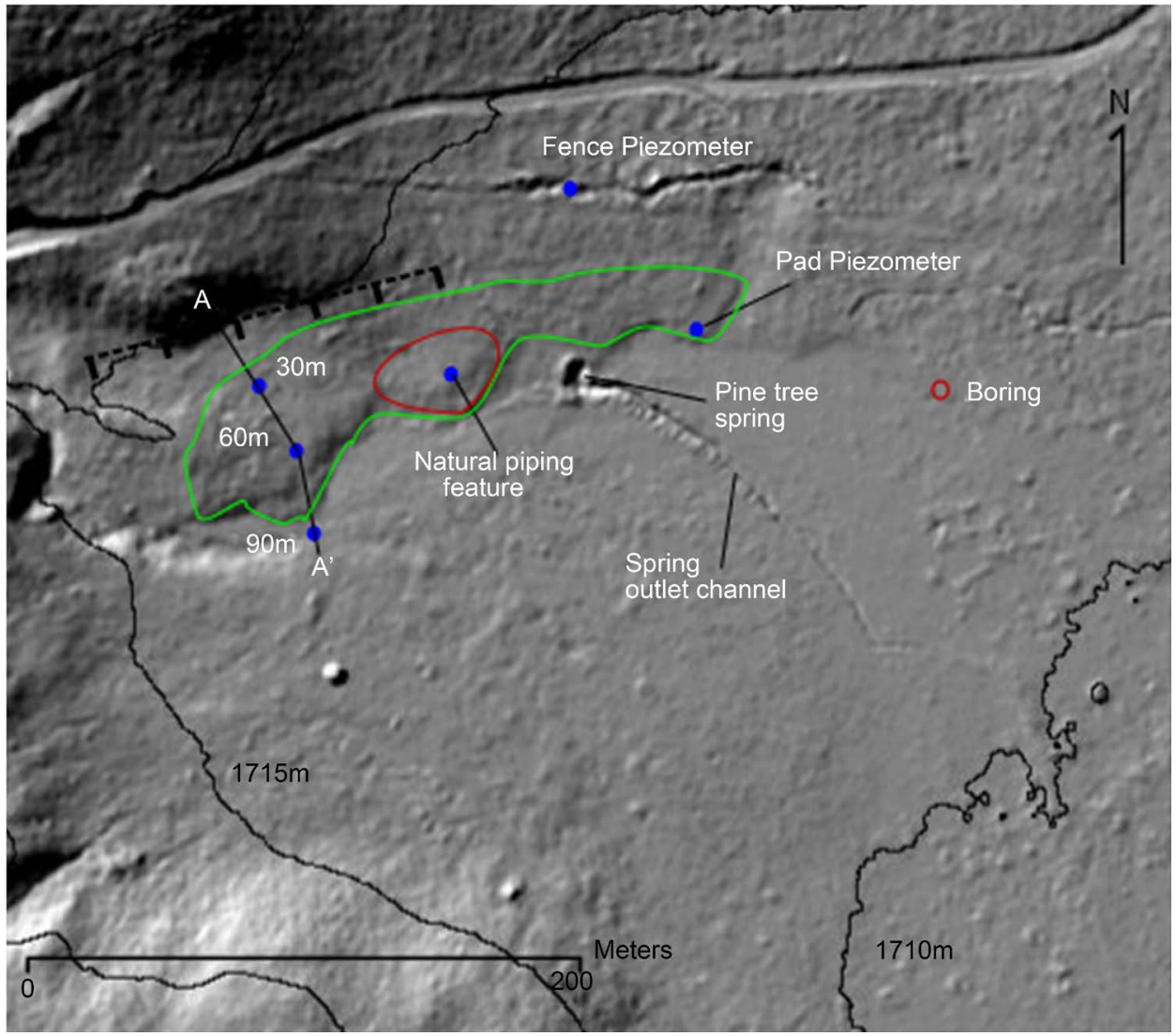

Figure 7. Northwest wetland and fen. The red line outlines the fen. Within this area peat is up to $1.1 \mathrm{~m}$ thick. The blue dot within the red line is a naturally occurring piping feature where surface flow from the pumice aquifer occurs most years. The green line outlines the area of the wetland. The berm that separates the wetland from drier areas follows the southern green line. The inferred trace of an east-northeast striking normal fault (down to the south) is shown by the black dashed line. 
Table 1. Oxygen and hydrogen isotopic ratios for Round Meadow.

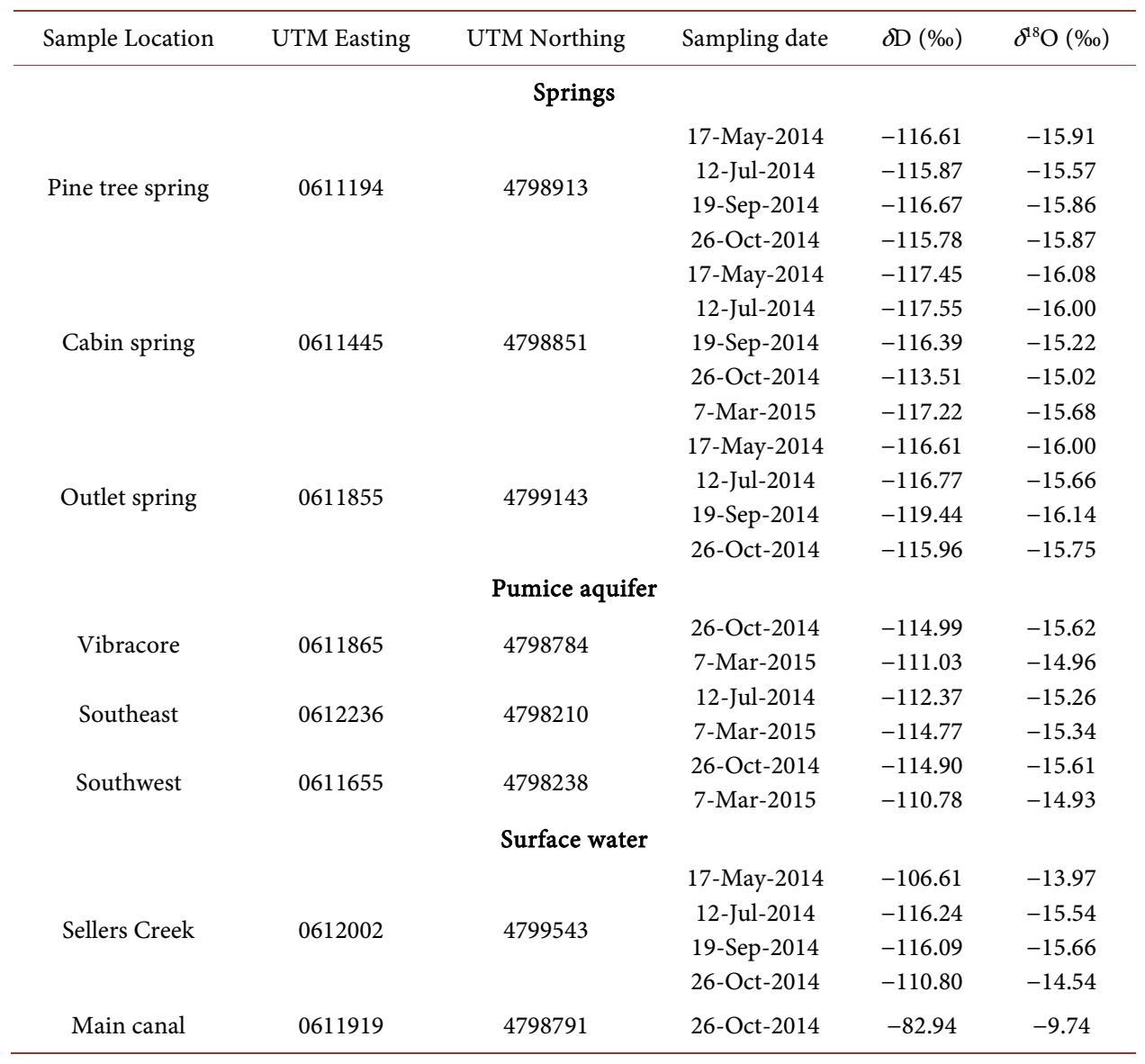

Analyzed by Colorado Plateau Stable Isotope Lab, Flagstaff, Arizona.

west are less defined. To the west, lodgepole pine, bitterbrush understory, and absence of organic-bearing silt suggest the wetland does not extend west of the green line shown in Figure 7. To the east beyond pad piezometer the percent surface covered by vegetation decreases and organic-bearing silt is not present. Within the wetland, the boundary layers of the pumice aquifer are an underlying silt (Pliocene?), overlying silt and organic-bearing silt to fine-grained sand, and peat (fen). Roughly coincident with the berm and ephemeral stream valley, lateral permeability within the pumice aquifer is reduced by iron oxide precipitate.

Throughout the wetland $(30 \mathrm{~m}, 60 \mathrm{~m}$, and pad piezometer, inferred in natural piping feature) and in the $90 \mathrm{~m}$ piezometer and the boring east of the wetland, only the lower pumice unit was present (Figure 7). The thickness of the overlying pumice-bearing silt ranged from 10 to $55 \mathrm{~cm}$ thick beneath the wetland and up to $115 \mathrm{~cm}$ thick at the $90 \mathrm{~m}$ piezometer and boring east of the wetland. Within the wetland, this pumice sand-bearing silt was overlain across sharp contact by 15 to $22 \mathrm{~cm}$ of organic-bearing silt and in the vicinity of the natural piping feature by up to $1.1 \mathrm{~m}$ of peat. Roughly at the western green boundary line in Figure 7, the ground surface rises by about 20 to $40 \mathrm{~cm}$, vegetation changes, and a tree root ball at an elevation above $1715 \mathrm{~m}$ excavated the upper 
pumice unit at the surface. Two auger holes passed through the pumice aquifer, the 60 $\mathrm{m}$ and $90 \mathrm{~m}$ piezometers in transect A-A', and penetrated silt believed to correlate to the diatomaceous silt (Pliocene?) beneath the confined pumice aquifer under the seasonally flooded meadow and refusal against resistant bedrock believed to be the welded tuff, respectively.

Beneath the wetland, the pumice aquifer was at least partially confined by the silt layers and peat layer. Within the fen, the peat layer was up to $1.1 \mathrm{~m}$ thick and thinned in all directions away from the natural piping feature. This peat layer extended, but thinned, toward the excavation for pine tree spring. Bryophytes are abundant throughout the area underlain by peat. Aldous et al. [2] reported groundwater flow direction in the peat layer to the east southeast toward pine tree spring during field investigations in 2009. The shallow piezometers used in that study did not penetrate the underlying pumice aquifer. The natural piping feature within the fen extends to at least $240 \mathrm{~cm}$ beneath the fen surface and rises from the pumice aquifer upward through the peat layer. Surface flow from the natural piping feature was observed in WY2011, WY2012, and WY2013 into July. However, surface flow was not observed after 4-July-2013 and the end of WY2015. In WY2014 and WY2015, the springtime water table was within $4 \mathrm{~cm}$ of the ground surface, but end of water year levels declined so that by the end of WY2015 the water table was over $1 \mathrm{~m}$ beneath the ground surface, probably near the pumice-peat contact (Figure 8). In WY2014 and WY2015 discharge through the fen

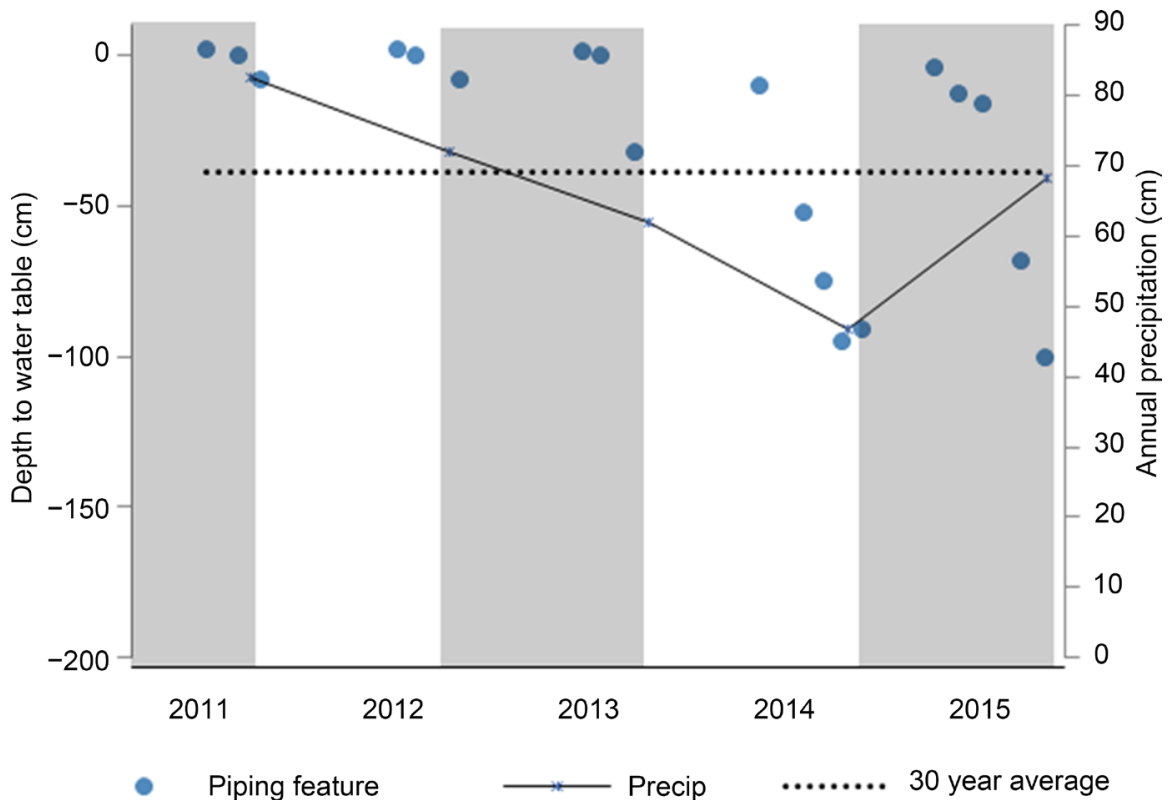

Figure 8. Depth to water table relative to ground surface measured at the natural piping feature in the fen. Surface flow from the piping feature was observed in WY2011, WY2012, and WY2013 at least into July. The last date surface flow from the piping feature was observed was 3-July-2013. The solid line is the cumulative precipitation received in each water year and the dashed line is the average precipitation for the period of record at the Chemult Alternate SNOTEL site (http://www.wcc.nrcs.usda.gov/nwcc/site?sitenum=395) located $18 \mathrm{~km}$ southwest of Round Meadow and $230 \mathrm{~m}$ lower in elevation. 
face ceased, bryophytes turned brown, and the springy character of the peat layer decreased. Recharge of the pumice aquifer during snowmelt in WY2016 (13-May-2016) restored weak flow from the natural piping feature, surface water seepage across the fen surface, and surface flow from the fen across a low point in the berm to the excavation at pine tree spring. As suggested by depth to water table relative to cumulative precipitation for water years between WY2011 and WY2015 (Figure 8) the fen is sensitive to annual precipitation patterns and recharge of the pumice aquifer.

Elsewhere in the wetland, the silt-rich layers that overlie the pumice aquifer are confining layers. When the pad and $60 \mathrm{~m}$ piezometers (Figure 7) were installed (4-July-2013), water rose to or near the surface when the pumice aquifer was penetrated $(62 \mathrm{~cm}$ rise at pad piezometer, less at $60 \mathrm{~m}$ ). In general, vegetation in these areas was dominated by sedges and rushes.

The pumice-bearing sandy silt and organic-bearing silt form a confining layer over the pumice aquifer within the wetland, however, the lower pumice unit, the aquifer, extends in the subsurface beyond the boundaries of the wetland. Lateral flow within the pumice aquifer is restricted by iron oxide precipitation and cementation. This zone of reduced permeability is inferred to coincide with the berm that marks the southern boundary of the wetland. Three lines of evidence support this interpretation. First, vegetation changes abruptly at the berm with lush sedges, rushes, and bryophytes growing in organic-bearing silt north and on the berm and discontinuous patches (about 30\% cover) of yarrow and strawberries growing in silt south of the berm. Second, depth to water table in the $60 \mathrm{~m}$ and $90 \mathrm{~m}$ piezometers, both screened in the pumice aquifer, was distinctly different. Same date measurements indicate the depth to water table in the 90 $\mathrm{m}$ piezometer was distinctly greater than in the $60 \mathrm{~m}$ piezometer. The average elevation difference was $85 \mathrm{~cm}$ (STDEV $=25 \mathrm{~cm}, \mathrm{n}=9$, 4-July-2013 to 26-Sept-2015). Third, iron oxide precipitates and cementation within the pumice aquifer particularly near the bedrock contact in the $90 \mathrm{~m}$ piezometer was prominent. Stagnation of groundwater in the late summer within the pumice aquifer is associated with declining oxidation-reduction potential and increased iron concentration in the groundwater as indicated in the chemical analyses reported earlier. As this reduced groundwater is pushed through the aquifer during the next freshet, oxidation takes place and iron is precipitated within the aquifer. Ground penetrating radar (GPR) and electrical resistivity models reported by Sanders [15] were consistent with these observations and suggested the northwest wetland/fen was associated with a small graben.

How the wetland and fen are related to pine tree spring remains to be considered. Until WY2014, the spring and the wetland were interpreted to be part of the same system and the direction of flow within the peat layer in the fen determined by Aldous et al. [2] in WY2009 suggested the spring was a discharge point for the fen. On 13-May-2016 this interpretation was reinforced by surface flow from the fen across the peat layer and into the excavation at pine tree spring. However, during the drought of WY2014 and continuing through WY2015 seepage from the thin peat layer and underlying rounded pumice-bearing silt exposed in the banks of the excavation ceased. In addition to this observation, three lines of evidence suggested pine tree spring and the wetland/fen were 
not part of the same system. 1) Water temperature in the fen and wetland followed seasonal warming and cooling while temperature of pine tree spring was cooler in summer and warmer in fall and spring than the wetland/fen. 2) Discharge from the spring did not change during WY2014 $\left(\sim 1 \times 10^{-3} \mathrm{~m}^{3} / \mathrm{s}\right)$ while the water table in the fen declined by nearly $100 \mathrm{~cm}$. 3) In WY2015, recession of the water table and lack of seepage from the peat and silt layer in the excavation were observed, but discharge from the spring decreased by approximately half. These lines of evidence suggested pine tree spring and the wetland/fen are supported by different groundwater systems. The spring is fed by deeper circulating groundwater rising along faults and fractures cutting the welded tuff while the wetland and fen are primarily fed by groundwater moving through the pumice aquifer. However, we cannot rule out contribution to the fen and wetland from groundwater rising along faults and fractures cutting the welded tuff [15].

\section{Springs}

Hydrogeologic features inherited from the pre-eruption landscape include low-volume springs that discharge within the northern meadow fringe (Figure 2). At all three springs, the welded tuff is either exposed or inferred to be present. Since the springs have a similar distribution as the welded tuff outcrops in the northern fringe and the welded tuff is offset by faults in the northwest part of the meadow [15] and likely at the knickpoint, it was inferred that the springs are the surface expression of fracture flow within this bedrock unit.

The combined discharge from pine tree and cabin springs was $2 \times 10^{-3} \mathrm{~m}^{3} / \mathrm{s}$ and remained consistent for monthly measurements between April and October, 2014. However, in WY2015 the discharge decreased by approximately half by the end of the water year. The discharge from these springs (Figure 2 and Figure 7) was carried in excavated canals toward the seasonally flooded meadow, but in both cases, the spring outflow in the canals was perched over silt-rich deposits that overlie the pumice aquifer. The outflow spreads out across the surface at the terminus of the canals.

Discharge at the third spring, outlet spring, flows directly into Sellers Creek. Discharge for this spring was determined by measuring discharge in Sellers Creek above and below the confluence of a channel from the spring to the creek. Visual inspection suggested discharge from the spring was relatively constant, but decreased by about half by the end of WY2015. However, calculated discharge varied from $1 \times 10^{-3}$ to $1.1 \times 10^{-2}$ $\mathrm{m}^{3} / \mathrm{s}$ during WY2014 reflecting difficulties in accurately measuring discharge in Sellers Creek. In WY2014, isotopic ratios indicate discharge from the seasonally flooded meadow over the knickpoint at the head of Sellers Creek ceased (see 7.0). However, discharge in Sellers Creek above the confluence with outlet spring was $4 \times 10^{-3} \mathrm{~m}^{3} / \mathrm{s}$ and 1 $\times 10^{-3} \mathrm{~m}^{3} / \mathrm{s}$, in August and September, respectively. Flow in the creek between the knickpoint and confluence is due to diffuse discharge from the left bank where remnants of the pumice aquifer overlie welded tuff. Outlet spring was probably the largest point of discharge in the first $280 \mathrm{~m}$ of Sellers Creek where welded tuff was bedrock.

Water temperature and electrical conductivity of spring effluent from all springs re- 
mained relatively constant over several years and were distinctly different from piezometers screened in the pumice aquifer. Water temperatures at all three springs varied between $5.0^{\circ} \mathrm{C}$ and $6.5^{\circ} \mathrm{C}$. The greatest variation was detected at outlet spring where the orifices were difficult to access. The water temperatures in piezometers varied from frozen to $12.4^{\circ} \mathrm{C}$. The water temperature was lower in March and distinctly higher in September in piezometers than in the springs. Likewise, electrical conductivity in the springs ranged from 32.4 to $48.4 \mu \mathrm{S} / \mathrm{cm}$, while conductivity of water in piezometers ranged from 30 to over $200 \mu \mathrm{S} / \mathrm{cm}$ and increased through the summer. The spring water at cabin spring was low sulfate $(0.19 \mathrm{mg} / \mathrm{l})$, low chloride $(0.37$ to $1.61 \mathrm{mg} / \mathrm{l})$, bicarbonate (22.8 to $28.8 \mathrm{mg} / \mathrm{l}$ ) water with $\mathrm{Na}^{+} / \mathrm{K}^{+}$ratios between 2.4 and 2.6 and $\mathrm{Ca}^{2+} / \mathrm{Mg}^{2+}$ ratios between 2.1 and 2.5. The $\mathrm{pH}$ was near neutral.

Hydrogen and oxygen isotopic ratios for the three springs were determined for four dates in WY2014 and ranged from $-113.51 \%$ o to $-119.44 \%$ and $-15.57 \%$ o to $-16.14 \%$, respectively (Table 1). Other than late season ratios from the spring box at cabin spring, the ratios plot near the GMWL. Evaporation from the spring box at cabin spring shifted values to the right of the GMWL in late season.

Water temperature, electrical conductivity, discharge, and isotopic ratios suggest that the water discharging from springs in the northern fringe have a common source, relatively short residence times, rise through fractures and faults in the welded tuff, but are sensitive to annual precipitation over a few years of stress in the aquifer. The springs do not appear to be influenced by the perched groundwater system in the pumice aquifer. The most significant contribution is to base flow in the first $280 \mathrm{~m}$ of Sellers Creek downstream from the knickpoint. This relation is discussed in the next section.

\section{Sellers Creek}

The head of Sellers Creek is arbitrarily set at the bedrock knickpoint that controls discharge from Round Meadow (Figure 2). From its head, Sellers Creek flows perennially for approximately $6.5 \mathrm{~km}$ (summer 2013 observations). Through much of this reach steep to overhanging banks flank the narrow channel which is incised to bedrock, mostly fault blocks of the welded tuff. The stream length with perennial flow in the Round Meadow watershed is $540 \mathrm{~m}$. The upper $280 \mathrm{~m}$ of the creek from the knickpoint is a gaining reach where it flows on welded tuff bedrock. The lower $260 \mathrm{~m}$ from the base of the welded tuff to the culvert at FSCR 9405 is a losing reach flowing over unknown bedrock.

Identification of processes and fluxes that controlled discharge in the perennially flowing reach of Sellers Creek within the Round Meadow watershed was accomplished using oxygen and hydrogen isotopic ratios. The first round of sampling on 17-May-2014 from three springs and Sellers Creek at FSCR 9405 (Figure 2) indicated water passing through the culvert at FSCR 9405 had experienced evaporation while groundwater discharging from springs had not (Table 1). However, the evaporation signature at the FSCR 9405 culvert disappeared as the summer progressed and the isotopic ratios became similar to those for outlet spring on 12-July and 19-September (Figure 9). The 


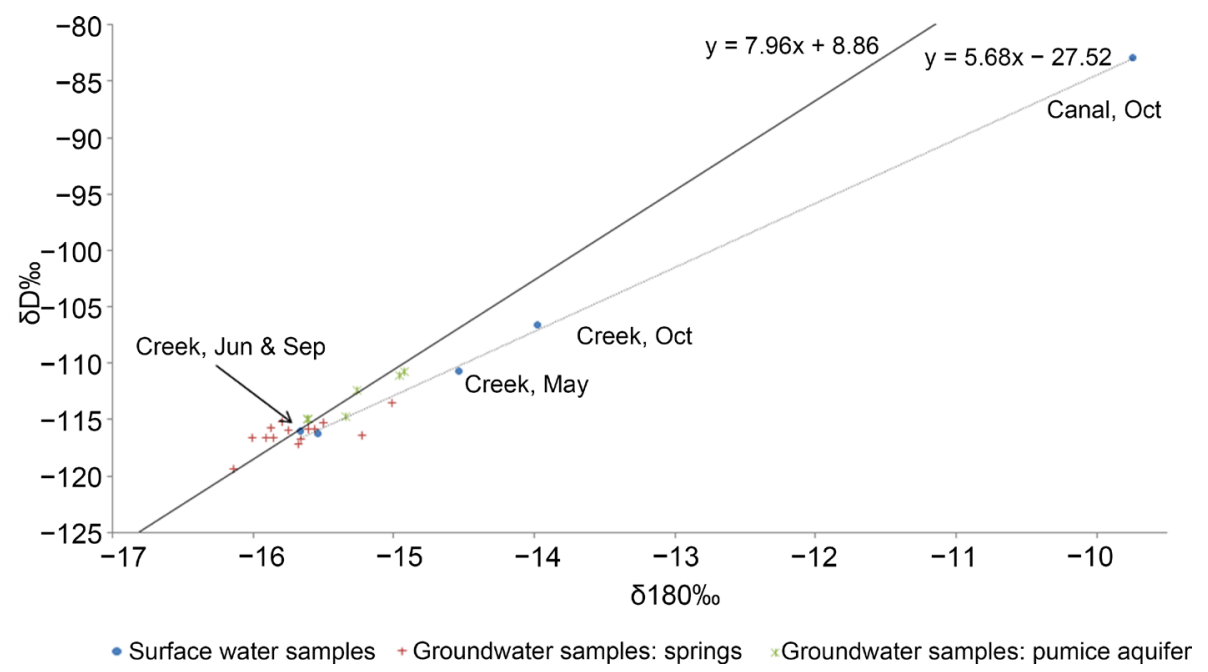

Figure 9. Isotope ratios for Round Meadow ground- and surface-water systems. Blue dots labeled "Creek, month" demonstrate the change in isotopic ratios of Sellers Creek during WY2014. The "Canal, Oct" is the isotopic ratio for the central canal before onset of winter precipitation in WY2015. Red symbols are isotopic ratios for springs and gray symbols are isotopic ratios for the pumice aquifer in Round Meadow during WY2014 and March of WY2015. Meteoric water line after Rozanski et al. [16].

evaporation signature at FSCR 9405 culvert was again prominent in a sample collected 24-Ocotober-2014. There are three potential sources of water for the perennially flowing reach: 1) surface water from the seasonally flooded meadow, 2) groundwater discharging to the creek from bedrock hosted seeps and springs such as outlet spring, and 3) groundwater from the confined pumice aquifer beneath the seasonally flooded meadow. Isotopic ratios for samples collected from Sellers Creek at FSCR 9405, the outlet spring, the main canal in the seasonally flooded meadow, and the confined pumice aquifer beneath the seasonally flooded meadow defined the relative contribution of these sources between May WY2014 and March WY2015 (Table 1).

Evaporation in the broad, shallow, seasonally flooded meadow imparts a distinct isotopic signature to surface water passing over the knickpoint at the head of Sellers Creek. As water levels decrease in the meadow flow over the knickpoint decreases and becomes focused where the central canal is located. Surface flow across the knickpoint was indicated by evaporation signatures at FSCR 9405 on 17-May and again on 24October, but not on 12-July and 19-September. The evaporation signature on 24-October occurred after the onset of autumn precipitation $(\sim 5 \mathrm{~cm}$ of rain within 3 days of sampling date) which increased discharge at the culvert from $1 \times 10^{-3} \mathrm{~m}^{3} / \mathrm{s}$ on 14 -September to $8 \times 10^{-3} \mathrm{~m}^{3} / \mathrm{s}$ on 24 -October. The isotopic ratios for the central canal on 24-October were $\delta \mathrm{D}=-82.94 \%$ and $\delta^{18} \mathrm{O}=-9.74 \%$.

The second water source contributing to perennial flow in Sellers Creek was the seeps and springs along the left bank in the first $280 \mathrm{~m}$ of the creek where it is flowing over fractured welded tuff. The isotopic ratios for outlet spring are presented in Table 1. The isotopic ratios for Sellers Creek at FSCR 9405 culvert on 12-July and 19-September indicated flow in the creek was sourced from the seeps and springs discharging ground- 
water from the welded tuff.

Contributions from the confined pumice aquifer beneath the seasonally flooded meadow to Sellers Creek were minor or absent. This is supported by three observations: 1) the elevation of the confined aquifer beneath the meadow is lower than the knickpoint, 2) the isotopic ratios for groundwater from the confined aquifer are heavier than those for outlet spring (Table 1), and 3) a pressure transducer indicated groundwater in the confined aquifer could not contribute to flow over the knickpoint. The pressure curve for the confined aquifer and the cumulative precipitation curve for the Chemult Alternate SNOTEL site are presented in Figure 10. The pressure curve suggests water levels in the seasonally flooded meadow exceeded the knickpoint when pressure was approximately $0.097 \mathrm{Mpa}$. Water pressure was below this value from the start of the record on 12-July-2014 when depth to water table was measured at $50 \mathrm{~cm}$ below ground surface (bgs). On 24-October-2014, the date the isotope samples were collected from Sellers Creek and the central canal, the water table was $96 \mathrm{~cm}$ bgs.

The isotopic ratios and pressure data elucidate the surface-and ground-water interactions in the perennially flowing reach of Sellers Creek within the Round Meadow watershed. When flow over the knickpoint from Round Meadow is absent, discharge in Sellers Creek is spring effluent from the welded zone of the welded tuff. Communication between the pumice aquifer beneath the seasonally flooded meadow and surface water in the meadow is unlikely and groundwater in the pumice aquifer is trapped beneath the meadow behind bedrock that forms the knickpoint separating the meadow from Sellers Creek. However, surface-water discharge over the knickpoint may occur when the water table in the confined pumice aquifer is below the elevation of the

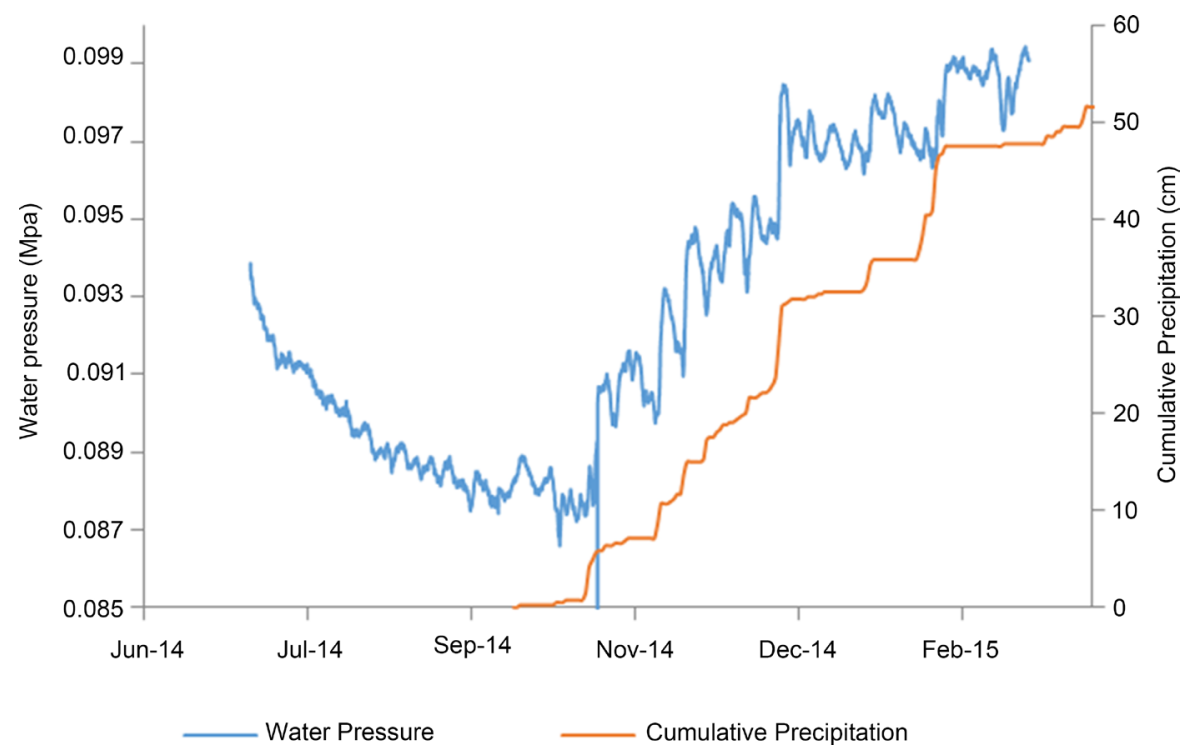

Figure 10. The blue curve is water pressure in Mpa from the pressure transducer in a piezometer screened in the pumice aquifer beneath the seasonally flooded meadow. The record starts on 13-July-2014. The red line is the cumulative precipitation curve in $\mathrm{cm}$ for WY2015 from the Chemult Alternative SNOTEL Station. The water pressure at which flow over the knickpoint is initiated is approximately $0.097 \mathrm{Mpa}$. 
knickpoint.

\section{Discussion}

Conditions during two back-to-back water years, WY2014 when the watershed experienced severe drought conditions and WY2015 when winter precipitation fell as rain and little snow pack accumulated [17] [18], surface and groundwater systems were stressed. Under these conditions, discrete sources, storage, and fluxes of water could be identified within the Round Meadow watershed. These determinations were further elucidated within the context of WY2011, WY2012, and WY2013 when precipitation was near or above average and winter precipitation fell primarily as snow. Depth to water table, spring and stream discharge, water temperature and electrical conductivity, water chemistry, and water budget [11] revealed hydrologic systems that while united by proximity, functioned independently. The discussion will first examine the evolution of the Round Meadow watershed focusing on processes that have disrupted the original lateral continuity of the Plinian pumice fall. The second section will present a conceptual model of the geohydrology of the Round Meadow watershed. The third topic of discussion explores the characteristics of headwater watersheds in pumice-blanketed landscapes.

\subsection{Evolution of the Round Meadow Watershed}

The characteristics of the pre-eruption landscape, Plinian pumice fall, and post-eruption modifications of the pumice deposit control interactions between the surface- and groundwater systems in the Round Meadow watershed. Groundwater flow pathways in the low-relief, pumice-blanketed landscape are controlled by permeability contrasts between primary pumice and silt-rich reworked deposits and, locally, precipitates of iron oxides. Surface water occurs where silty reworked deposits underlie the seasonally flooded meadow and ephemeral stream valley network. Perennial stream flow is limited to Sellers Creek between the knickpoint and the culvert at FSCR 9405. Base flow in this reach is maintained by groundwater discharge from fractured welded tuff bedrock. Isotopic ratios suggest this groundwater source is distinct from the groundwater in the pumice aquifer.

Pre-eruption topography, litholigies, and faults constrained evolution of the pumice aquifer after the eruption. Pre-eruption topography provided the template that influenced the post-eruption hydrologic response in three ways. 1) Modern ephemeral stream valleys that guide groundwater flow pathways in the pumice aquifer follow topographically low areas inherited from the pre-eruption landscape. 2) Resistant bedrock at the knickpoint and low permeability diatomaceous silt (Pliocene?) preserved on the downthrown block allowed stacking of deposits formed in a wetland in the pre-eruption landscape, shallow lake in the post-eruption landscape, and modern seasonally flooded meadow. 3) Low-volume springs that discharge from fractures and faults in the welded tuff along the northern fringe of the meadow likely contributed to perennial flow in Sellers Creek and wetlands along the northern fringe of the meadow 
in the pre- and post-eruption landscapes.

The Plinian pumice fall that buried the landscape was initially laterally uniform in grain size, sorting, thickness, and lacked groundwater. The pumice blanket covered low permeability bedrock and regolith throughout the watershed. Particularly in the northern fringe where the pumice blanket overlaid faulted and fractured welded tuff, groundwater was introduced into the base of the blanket. Concurrently, precipitation contributed to surface rill formation and infiltration into the nascent groundwater system. How the surface-and ground-water systems evolved in relation to the pumice blanket produced the modern distribution of storage and fluxes of water in different parts of the watershed. The watershed can be examined in three settings: 1) the higher relief slopes present in the uplands of the watershed, 2) the low relief slopes of the meadow fringe, and 3) the seasonally flooded meadow.

The uplands are underlain by olivine basalt lava flows, remnants of small shield volcanoes. Here, the rill network coalesced to form channels that are cut to bedrock where they fall over topographic breaks held up by the moderately resistant lava flows. During the freshet stream flow may occur in these bedrock-lined channels. Away from these channels infiltrated snow melt migrates downward through the pumice blanket to the pre-eruption surface where groundwater moves downslope or is consumed by evapotranspiration.

From the slope breaks with the upland areas to the seasonally flooded meadow and including the meadow fringe, weakly consolidated diatomaceous silt (Pliocene?), locally overlain by younger basalt flows is present. Here, early rapid incision scoured into and locally through the upper pumice unit, but this early stage of scouring was followed by deposition of silt-rich alluvium and the evolution of flat-bottomed valleys similar to those described by Blong [19] on the North Island of New Zealand. The alluvium partitions surface water from groundwater. During the freshet, surface water sinks into the alluvium where it is either consumed by evapotranspiration or joins the groundwater flow paths in remnants of the underlying pumice aquifer. This process was observed on 7-March-2015 and 13-May-2016 in the stream channel that enters the seasonally flooded meadow from the southeast. Locally, as in the northwest wetland and fen, groundwater discharging into the pumice aquifer from fractures in the welded tuff [15] may have provided moisture conditions that allowed vegetation to colonize the alluvium and contribute to accumulation of organic-bearing silt. This, in turn, contributed to redox reactions that allowed iron oxide precipitation in the underlying pumice aquifer. These processes contributed to increased isolation of the wetland from its original groundwater source and separation of the wetland and fen from pine tree spring.

Progressive isolation of groundwater from surface water also occurred in the seasonally flooded meadow where diatomaceous silt deposited in the post-eruption lake formed a confining layer that separated the hybrid pumice aquifer from the overlying seasonally flooded wetland. Flotation of coarse pumice lapilli and blocks from the upper pumice unit produced a lag of phenocrysts and lithic fragments on the lake bed. Saturation and settling of pumice in the lake buried the lag sand with pumice sand and 
gravel. Thus, the hybrid aquifer beneath the seasonally flooded meadow is comprised of primary pumice of the lower pumice unit, the lag sand, and the reworked pumice gravel.

\subsection{Conceptual Model for the Round Meadow Watershed}

A conceptual model for the Round Meadow watershed is dominated by interactions of ground- and surface-water in the meadow fringe and seasonally flooded meadow. Input is dominated by precipitation. Weatherford [11] determined that in WY2014, a drought year, $95 \%$ of the water entering the watershed was from precipitation and $79 \%$ of that fell from October to April. Five percent (5\%) entered as groundwater discharging from the welded tuff through springs. However, most of this groundwater discharged directly to Sellers Creek and interacted with neither the meadow fringe nor seasonally flooded meadow. Output is dominated by evapotranspiration. From April through September in WY2014, 98\% of the water that left the watershed was due to evapotranspiration. Calculation of evapotranspiration was weighted toward the seasonally flooded meadow where the well-watered surface assumed in the Penman evapotranspiration calculation was best approximated from July to the end of the water year [11]. The conceptual model is biased toward storage in and beneath the seasonally flooded meadow, the key component for tracking water fluxes in this headwaters watershed.

The schematic diagram presented in Figure 11 roughly follows a north-northeast cross section from the southern margin of the watershed to the culvert beneath FSCR 9405. The cross section follows a hypothetical pathway along a stream valley in the south and Sellers Creek in the north. Hydrographs for piezometers screened in the pumice aquifer indicate the timing of recharge is, in most years, between April and early June with maximum storage probably occurring in May. After this recharge period the water table recedes steadily with lowest levels during September and October. Summer precipitation does not affect recharge of the aquifer. While this pattern plays out in the unconfined and confined pumice aquifer, a different pattern plays out in the seasonally flooded meadow. There, inundation is maximum as the snow on the meadow surface melts and, if it occurs, ephemeral streams discharge to the meadow. Discharge from the meadow across the knickpoint adjusts to the expansion and contraction of the area of inundation. The contribution of surface water from the meadow to Sellers Creek is demonstrated by the isotopic ratios at the culvert beneath FSCR 9405. In WY2014 samples collected at this site in May indicated the effect of evaporation in the meadow on the isotopic ratios of stream discharge. This evaporative signal disappeared from Sellers Creek on the July and September sampling dates when spring water discharge from the welded tuff produced stream flow in Sellers Creek. The evaporation signal appeared again in late October after early autumn precipitation raised water levels in the meadow

to allow discharge from the central canal across the knickpoint. The response of the seasonally flooded meadow to snowmelt and summer/autumn rainfall is independent of the groundwater system in the unconfined and confined pumice aquifer. We cannot rule out discharge upward from the confined aquifer through the deeper excavated 


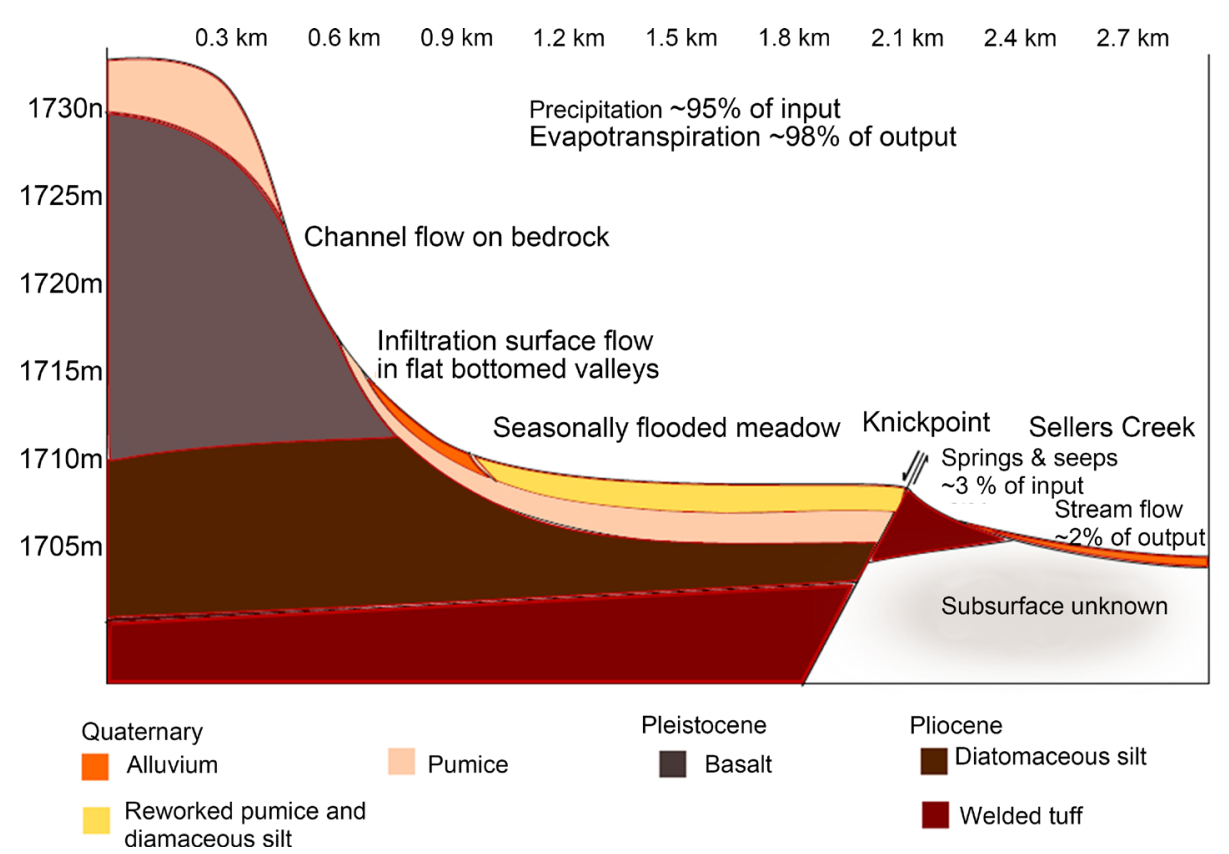

Figure 11. A conceptual model of flow paths and storage in the pumice aquifer. Above approximately $1710 \mathrm{~m}$ snowmelt from winter precipitation soaks into the pumice deposit and locally supports surface flow in ephemeral streams during the freshet. Water entering the pumice aquifer migrates toward the seasonally flooded meadow where it recharges the confined hybrid pumice aquifer that underlies the meadow. Below $1710 \mathrm{~m}$, precipitation falls on low permeability silt that forms the upper confining layer for the hybrid pumice aquifer beneath the seasonally flooded meadow and supports surface flow in Sellers Creek until water levels fall below the elevation of the knickpoint. Precipitation provides approximately $95 \%$ of the input to the watershed while $5 \%$ is provided from springs. In this figure, $\sim 3 \%$ of the total input is provided by the outlet spring and associated seeps. Approximately $98 \%$ of the water removed from the watershed is by evapotranspiration while approximately $2 \%$ leaves by surface flow through Sellers Creek. The cross section is constructed along imaginary ephemeral stream beds and the channel of Sellers Creek.

canals given the positive head in the confined aquifer. However, the strong evaporation signature of a sample collected on 26-October-2014 from the central canal suggests such upward discharge from the confined aquifer in late season is minor or absent (Table 1). We also cannot rule out discharge from the confined aquifer across the knickpoint at the head of Sellers Creek. However, due to the stratigraphic and structural relations illustrated in Figure 11, much of the confined aquifer is at lower elevation than the knickpoint.

The northwest wetland/fen and springs play locally important roles in sustaining biodiversity [2] [20] and perennial flows to the meadow and Sellers Creek. Regionally, these groundwater dependent systems influence the freshwater ecology of the larger basin [3] [21]. The dilute groundwater discharged at the 3 springs is different from the groundwater in the pumice aquifer based on temperature, conductivity, and isotopic ratios. The fact that all 3 springs had relatively undiminished flow despite the drought of WY 2014 indicates that they are sourced in a system that is less responsive than the pumice aquifer to seasonal variability. Persistent low temperatures suggest that the wa- 
ter is moving at depths of $10 \mathrm{~m}$ or greater. However, the low electrical conductivity (32.4 to $48.4 \mu \mathrm{S} / \mathrm{cm}$ ) and chemical composition suggest these waters do not circulate to great depth or for long periods of time. The short residence time is further suggested by the late season decline in discharge in WY2015. Differences between spring water and groundwater within the pumice aquifer suggest that the springs are recharged outside of the Round Meadow basin. This effect was found to be common in basins with frequent Quaternary volcanism [22]. The lighter isotopic signature suggests a higher recharge elevation [23]. The proximity of Walker Rim, about $300 \mathrm{~m}$ higher and $6 \mathrm{~km}$ to the west offers a source which fits these data, but no evidence is known to directly link the areas.

The relation between the northwest wetland/fen and pine tree spring suggest early co-evolution of these environments followed by increased isolation as the landscape continued to respond after burial during the Plinian eruption of Mount Mazama. Pre-eruption seeps and low volume springs discharging from faults and fractures in the welded tuff [15] continued to discharge after burial producing the earliest groundwater system. As infiltration and lateral migration of groundwater in the pumice blanket increased through time, additional groundwater was contributed to the site. Concurrently, early stream erosion scoured into the lower pumice. Deposition of silt-rich alluvium followed, and in the auger holes in the wetland, the silt-rich alluvium abruptly changed to silt-rich, organic-bearing alluvium suggesting favorable conditions for plant growth. Where the fen is located, peat in inferred to overlie the pumice. Seasonal stagnation in the pumice aquifer and organic debris allowed iron leaching from the pumice. Where this iron-bearing water encountered oxidized groundwater in the aquifer, iron oxide precipitation reduced permeability in the pumice aquifer. Thus, through time, the wetland/fen became increasingly isolated within the pumice aquifer, from the surface, and from pine tree spring. We cannot rule out groundwater contribution to wetland and fen from fault-related sources which are believed to control discharge at pine tree spring. However, greater water table declines in WY2013, WY2014, a drought year, and WY2015, a year dominated by winter rainfall rather than snowfall [17] [18], suggest the fen is primarily dependent on annual precipitation patterns (Figure 8). Apparently, in wet years, groundwater from the fen flows toward the spring as suggested by head measurements in the peat layer of the fen reported by Aldous et al. [2]. However, discharge through the fen face ceased under drought conditions. The recharge of the wetlands and fen is inferred to rely mostly on groundwater from the unconfined pumice aquifer.

\subsection{Hydrogeology in Pumice-Blanketed Headwaters Watersheds}

At Round Meadow, throughout the Walker Rim study area [1] [2] [20], and in the headwaters of the Deschutes basin on the east flank of the Cascade Range [3] discharge from the perched unconfined pumice aquifer and near-surface storage of groundwater supports diverse biological communities in these pumice-blanketed headwaters basins. Near-surface storage is maximum after the snow melts and decreases steadily through the growing season to minimum storage in late September and October. Recharge of 
the pumice aquifer is overwhelming snow melt, but locally, deeper seated groundwater rising along faults and fractures or migrating along permeable contacts in the volcanic bedrock may provide recharge. In low relief settings, contrasts in permeability between the primary pumice deposit and the alluvium in ephemeral stream valleys, silt layers deposited in short-lived post-eruption lakes, or, in the case of fens, peat, restrict movement within the pumice aquifer and isolation of surface- and ground-water systems. Iron oxide precipitation within the aquifer and along contacts between the primary pumice deposit and alluvium also provide barriers to groundwater movement.

Channels with perennial surface flow are rare in the pumice-dominated headwater watersheds. In the case of Round Meadow watershed, perennial flow in WY2014 occurred only in artificial outflow channels from pine tree and cabin springs, and in the $520 \mathrm{~m}$ of Sellers Creek between the knickpoint and the culvert at FSCR 9405. Groundwater discharge from the welded tuff provided this flow. Jaeger et al. [24] illustrated difficulties identifying the initiation of perennial flow in forested watersheds in southwestern Washington and how the uncertainty impacts management practices.

\section{Conclusions}

The slope and topography of the pre-eruption landscape controlled post-eruption landscape evolution and emergence of the modern hydrogeologic system in the Round Meadow watershed. Early rill network formation guided valley formation and the ephemeral stream network that dominates the watershed. Blockage of the outlet of Round Meadow during the eruption allowed a lake to form in the meadow and removed, by flotation, the coarse-grained upper pumice unit. Flotation of pumice and wave action produced the hybrid aquifer that underlies the seasonally flooded meadow. Subsequent change from lacustrine to paludal environments isolated the perched groundwater system in the hybrid pumice aquifer from the surface water in the meadow.

Springs along the northern meadow fringe discharge from faults and fractures in the welded tuff. The discharge from these springs is a volumetrically minor component of the water budget of the watershed, but contributes to perennial discharge in Sellers Creek and to the meadow. Although the fen in the northwest corner of Round Meadow may receive some recharge from the fault and fracture system that cuts the welded tuff, it is sensitive to annual precipitation patterns and appears to be isolated from the groundwater system that discharges to the springs.

At the scale of these headwaters watershed, oxygen and hydrogen isotopic ratios delineate groundwater in the pumice aquifer from groundwater discharging at springs. Seasonal variations of isotopic ratios in Sellers Creek differentiates fluxes from the seasonally flooded meadow and the groundwater discharged from springs.

\section{Acknowledgements}

Comments by Robert Perkins on an early draft of this paper greatly influenced its organization and clarity. Several students supported data gathering for this project, chief 
among them are D. Eibert, L. Hoge, E. Lahart, and M. Robbins. Vibracore cores and samples were recovered with the help of A. Mowbray and M. Bordal.

\section{References}

[1] Cummings, M.L., Weatherford, J.M. and Mowbray, L.A. (2014) Hydrogeology of PumiceHosted Fens in the Winema-Fremont National Forest, Oregon, USA. Journal of Water Resource and Protection, 6, 1762-1780. http://dx.doi.org/10.4236/jwarp.2014.619158

[2] Aldous, A.R., Gurrieri, J.T., Bach, L.B., Congdon, R.D., Carlson, C.P., Carroll, T.A. and Nevill, M. (2014) A Groundwater Balancing Act: Environmental Flows and Levels for Groundwater-Dependent Fens of the Antelope Grazing Allotment, Fremont-Winema National Forest, Oregon. The Nature Conservancy and the USDA Forest Service, Portland, Oregon.

[3] Aldous, A.R., Gannett, M.W., Keith, M. and O'Connor, J. (2015) Geologic and Geomorphic Controls on the Occurrence of Fens in the Oregon Cascades and Implications for Vulnerability and Conservation. Wetlands, 35, 757-767. http://dx.doi.org/10.1007/s13157-015-0667-x

[4] Bacon, C.R. and Lanphere, M.A. (2004) Eruptive History and Geochronology of Mount Mazama and the Crater Lake region, Oregon. Geological Society of America Bulletin, 118, 1331-1359. http://dx.doi.org/10.1130/B25906.1

[5] Young, S.R. (1990) Physical Volcanology of Holocene Airfall Deposits from Mt. Mazama, Crater Lake, Oregon. Ph.D. Dissertation, University of Lancaster, Lancaster.

[6] Klug, C., Cashman, K.V. and Bacon, C.R. (2002) Structure and Physical Characteristics of Pumice from the Climactic Eruption of Mount Mazama (Crater Lake), Oregon. Bulletin of Volcanology, 64, 486-501. http://dx.doi.org/10.1007/s00445-002-0230-5

[7] Witham, A.G. and Sparks, R.S.J. (1986) Pumice. Bulletin of Volcanology, 48, 209-223. http://dx.doi.org/10.1007/BF01087675

[8] Manville, V., White, J.D.L., Houghton, B.F. and Wilson, C.J.N. (1998) The Saturation Behavior of Pumice and Some Sedimentological Implications. Sedimentary Geology, 119, 516. http://dx.doi.org/10.1016/S0037-0738(98)00057-8

[9] Bouwer, H. and Rice, R.C. (1976) A Slug Test for Determining Hydraulic Conductivity of Unconfined Aquifers with Completely or Partially Penetrating Wells. Water Resources Research, 12, 423-428. http://dx.doi.org/10.1029/WR012i003p00423

[10] Schwartz, F.W. and Zhang, H. (2003) Fundamentals of Groundwater. John Wiley \& Sons, New York.

[11] Weatherford, J.M. (2015) Hydrogeologic Investigation of a Pumice Aquifer, Fremont/ Winema National Forest, Oregon. M.S. Thesis, Portland State University, Portland, Oregon.

[12] Collins, B.D. and Dunne, T. (1986) Erosion of Tephra from the 1980 Eruption of Mount St. Helens. Geological Society of America Bulletin, 97, 896-905. http://dx.doi.org/10.1130/0016-7606(1986)97<896:EOTFTE >2.0.CO;2

[13] Major, J.J. and Mark, L.E. (2006) Peak Flow Responses to Landscape Disturbances Caused by the Cataclysmic 1980 Eruption of Mount St. Helens, Washington. Geological Society of America Bulletin, 118, 938-958. http://dx.doi.org/10.1130/B25914.1

[14] Cummings, M.L. (2007) Groundwater Capture of Surface Drainage during Post-Eruption Landscape Evolution, Williamson River Basin, Oregon. Hydrological Science and Technology, 23, 79-90.

[15] Sanders, M. (2016) A Geophysical Investigation of the Round Meadow Pumice Aquifer. 
M.S. Project Report, Portland State University, Portland, Oregon.

[16] Rozanski, K.L., Araguás-Araguás, L. and Conginatini, R. (1993) Isotopic Patterns in Modern Global Precipitation. In: Swart, P.K., Lohmann, K.C., Mckenzie, J. and Savin, S., Eds., Climate Change in Continental Isotopic Records, Geophysical Monograph Series Vol. 78, American Geophysical Union, Washington DC, 1-36.

[17] Cummings, M.L., Weatherford, J.M. and Eibert, D.A. (2015) Recharge of an Unconfined Pumice Aquifer: Winter Rainfall versus Snow Pack, South-Central Oregon. American Geophysical Union Fall Meeting, H43I-1658.

[18] Cummings, M.L., Weatherford, J.M. and Eibert, D.A. (2016) Rain- versus Snow-Dominated Winter Precipitation and Recharge of the Perched Pumice Aquifer, Walker Rim Study Area, Fremont-Winema National Forest, Oregon. 87 th Annual Meeting of the Northwest Scientific Association, Bend, Oregon, 23-26 March 2016, 49.

[19] Blong, R.J. (1970) The Development of Discontinuous Gullies in a Pumice Catchment. American Journal of Science, 268, 369-383. http://dx.doi.org/10.2475/ajs.268.4.369

[20] Aldous, A.R. and Bach, L.B. (2014) Hydro-Ecology of Groundwater-Dependent Ecosystems: Applying Basic Science to Groundwater Management. Hydrological Sciences Journal, 59, 530-544. http://dx.doi.org/10.1080/02626667.2014.889296

[21] MacDonald, L.H. and Coe, D. (2007) Influence of Headwater Streams on Downstream Reaches in Forested Areas. Forest Science, 53, 148-168.

[22] Jefferson, A., Grant, G. and Rose, T. (2006) Influence of Volcanic History on Groundwater Patterns on the West Slope of the Oregon High Cascades. Water Resources Research, 42, W12411. http://dx.doi.org/10.1029/2005wr004812

[23] Poage, M. and Chamberlain, C. (2001) Empirical Relationships between Elevation and the Stable Isotope Composition of Precipitation and Surface Water: Considerations for Studies of Paleoelevation Change. American Journal of Science, 301, 1-15. http://dx.doi.org/10.2475/ajs.301.1.1

[24] Jaeger, K.L., Montgomery, D.R. and Bolton, S.M. (2007) Channel and Perennial Flow Initiation in Headwater Streams: Management Implications of Variability in Source-Area Size. Environmental Management, 40, 775-786. http://dx.doi.org/10.1007/s00267-005-0311-2

Submit or recommend next manuscript to SCIRP and we will provide best service for you:

Accepting pre-submission inquiries through Email, Facebook, LinkedIn, Twitter, etc. A wide selection of journals (inclusive of 9 subjects, more than 200 journals)

Providing 24-hour high-quality service

User-friendly online submission system

Fair and swift peer-review system

Efficient typesetting and proofreading procedure

Display of the result of downloads and visits, as well as the number of cited articles

Maximum dissemination of your research work

Submit your manuscript at: http://papersubmission.scirp.org/

Or contact jwarp@scirp.org 